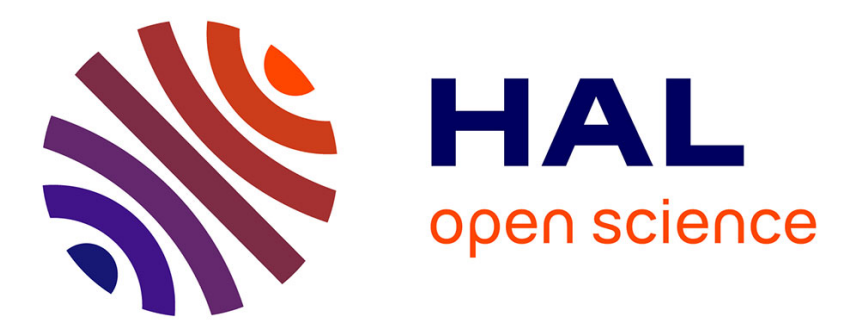

\title{
The long-run decline in the share of agricultural and food products in international trade: a gravity equation approach to its causes
}

\author{
Raul Serrano, Vicente Pinilla
}

\section{- To cite this version:}

Raul Serrano, Vicente Pinilla. The long-run decline in the share of agricultural and food products in international trade: a gravity equation approach to its causes. Applied Economics, 2011, pp.1. 10.1080/00036846.2011.587786 . hal-00716633

\section{HAL Id: hal-00716633 \\ https://hal.science/hal-00716633}

Submitted on 11 Jul 2012

HAL is a multi-disciplinary open access archive for the deposit and dissemination of scientific research documents, whether they are published or not. The documents may come from teaching and research institutions in France or abroad, or from public or private research centers.
L'archive ouverte pluridisciplinaire HAL, est destinée au dépôt et à la diffusion de documents scientifiques de niveau recherche, publiés ou non, émanant des établissements d'enseignement et de recherche français ou étrangers, des laboratoires publics ou privés. 


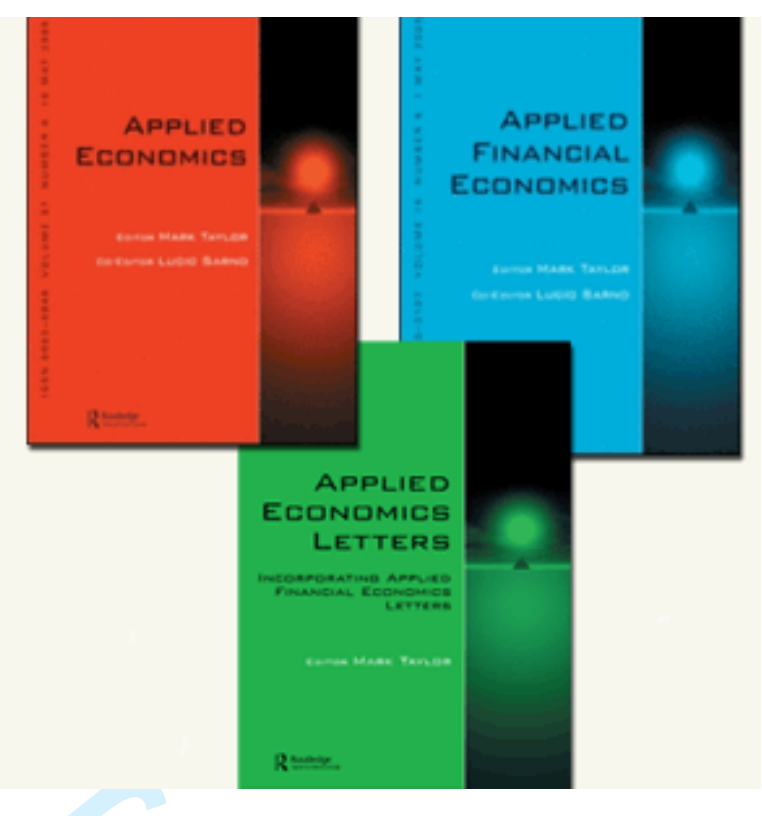

\section{The long-run decline in the share of agricultural and food products in international trade: a gravity equation approach to its causes}

\begin{tabular}{|c|c|}
\hline Journal: & Applied Economics \\
\hline Manuscript ID: & APE-2010-0250.R1 \\
\hline Journal Selection: & Applied Economics \\
\hline $\begin{array}{r}\text { Date Submitted by the } \\
\text { Author: }\end{array}$ & $25-O c t-2010$ \\
\hline \multirow[t]{2}{*}{ Complete List of Authors: } & $\begin{array}{l}\text { Serrano, Raul; University of Zaragoza, Applied Economics and } \\
\text { Economic History } \\
\text { Pinilla, Vicente; University of Zaragoza, Applied Economics and } \\
\text { Economic History }\end{array}$ \\
\hline & $\begin{array}{l}\text { N70 - General, International, or Comparative < N7 - Transport, } \\
\text { International, Domestic Trade, Energy, Other Services < N - } \\
\text { Economic History, N50 - General, International, or Comparative < } \\
\text { N5 - Agriculture, Natural Resources, Environment, and Extractive } \\
\text { Industries < N - Economic History, F14 - Country and Industry } \\
\text { Studies of Trade < F1 - Trade < F - International Economics, Q17 - } \\
\text { Agriculture in International Trade < Q1 - Agriculture < Q - } \\
\text { Agricultural and Natural Resource Economics }\end{array}$ \\
\hline Keywords: & Agri-food trade, International trade, gravity model, Second \\
\hline
\end{tabular}




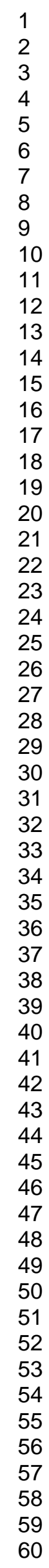

\section{SCHOLARONE ${ }^{m}$ \\ Manuscripts}

10

12

13

14

15

16

18

19

20

22

23

25

26

27

28
29

30

32

33

34

35

36

39

40

41

42

44

45

46

47

48

49

51

52

54

55

57

58

59

60 
The long-run decline in the share of agricultural and food products in international trade: a gravity equation approach to its causes

Raúl Serrano $^{\mathrm{a}^{*}}$ and Vicente Pinilla ${ }^{\mathrm{b}}$

a Department of Business Administration, Universidad de Zaragoza, Spain, E-mail: raser@unizar.es

b Department of Applied Economics and Economic History, Universidad de Zaragoza, Spain.E-mail: vpinilla@unizar.es

* Corresponding author. E-mail: raser@unizar.es

Running title: Long-run decline in the share of agrifood products in international trade

The objective of this study is to determine the causes of the loss of share of agricultural products and food in international trade. The article compares, using a gravity model, the impact of various factors upon bilateral trade in agricultural products, in manufactures and in total trade, between 1963 and 2000 for a representative sample of 40 countries. The results clearly demonstrate how the low demand elasticity for agricultural products and food, the high degree of protectionism to which they were subjected and their meagre share in intra-industrial trade are the principal causes of their relatively slow growth.

Address for correspondence: Raúl Serrano, Department of Business Administration, Facultad de Ciencias Económicas y Empresariales, Gran Via 4, Universidad de Zaragoza, 50005 Zaragoza, Spain. E-mail: raser@unizar.es 


\section{Introduction}

One of the most important questions concerning international trade in the second half of the XX century is the profound change in its composition, characterized by an increase in the share of manufactured products and a sharp decline in that of agricultural and food products. In 1951 the latter accounted for $43 \%$ of the value of total world trade. In the year 2000 this figure was only $6.7 \%$. Part of this declining importance is explained by the relative fall in its prices (Serrano and Pinilla, forthcoming), but nevertheless the decrease in volume was also substantial. By volume, agricultural trade represented $29.6 \%$ of total trade in 1951, but by the year 2000 it had contracted to only $8.5 \%$. Simultaneously, the ratio of international agricultural trade to agricultural production grew far less than the ratio of international trade in manufactures to manufacturing production. Thus, while in 1951 the ratio of agricultural trade to agricultural output was 0.16 , somewhat higher than that of manufacturing trade to manufacturing output $(0.13)$, in 2000 the latter was 0.5 , considerably higher than the former $(0.37)$ (Serrano and Pinilla 2010: 3506). With regard to the causes of this declining share in terms of volume, we outline here some of the reasons most commonly described in the literature: generalized protectionism in the international markets for agricultural products; changes in consumption patterns related to rising income levels, the achievement of considerable savings in the industrial usage of raw materials and, lastly, the decreasing share of intra-industrial trade for the majority of products comprising the agricultural and food products trade (Aparicio et al., 2009).

We therefore believe that a comparative analysis of the determinants of trade in agricultural products and manufactures provides a deeper understanding of this important transformation of international exchanges. The literature concerned with the differential behavior of the distinct products comprising international trade at that time has tended to concentrate on two fundamental aspects: the upsurge of intra-industrial trade and the institutional obstacles to the development of exchanges.

While until 1945 international trade was primarily inter-industrial, based on the exchange of primary products for manufactures, and complementary between economic regions, from then onwards intra- 
industrial trade became progressively more important, based on the exchange of manufactures between developed countries (Krugman, 1995). Given this background, the Hecksher-Ohlin-Samuelson (HOS) models, in which the exchange of homogeneous products is the result of specialization in production and trade between countries with different endowments and factor intensities, are unable to explain the increasing importance of intra-industrial trade. The New Trade Theory developed by Helpman and Krugman (1985) offers an alternative explanation of the new trade pattern, focusing on the size of the domestic market, economies of scale, product differentiation and imperfect competition.

On the institutional side, some essential factors to take into account are the influence of GATT upon the volume of trade and progressive trade regionalization through regional trade agreements (Rose, 2005; Subramanian and Wei, 2007; Tomz et al., 2007; and Felbermayr and Kohler, 2006, Dell'Aquila, 1999; Diao, 2001).

In this context, the basic objective of the present study is to analyze the principal causes of the decline in the relative share of agricultural and food products in international trade in the second half of the XX century. The article is therefore a contribution to the empirical literature on the determinants of international trade, offering various ideas concerning the differences between agricultural trade and trade in other types of goods, especially manufactures, and concentrating on three principal questions: the changes in countries' market size, the changes in per capita incomes and, lastly, the effects of the various liberalization processes upon international markets. The long-term perspective employed is an innovation in this type of literature and significantly strengthens the foundations of established theories. Furthermore, the analysis by product type permits a deeper understanding of the problems and perspectives of different countries' trade, by concentrating on their specialization.

To compare the two product groups (agricultural and food products vs. manufactures), the present article estimates the gravity equation for the bilateral volume of agricultural trade, of manufactures and of total trade, analyzed separately and employing the same specification and the same group of countries. Concretely, using the UN-COMTRADE (2003) database, we have constructed, for the period 1963-2000, a new data panel for bilateral trade among 40 countries with a significant presence in international markets.

The empirical success of the gravity equation in explaining trade patterns has generated numerous subsequent articles, although very few have employed a long-term perspective. Both the pioneering work by Feenstra et al. (1998) and subsequent studies (Evenett and Keller, 2002, Fidrmuc, 2004, Jensen, 2006, 
and Schumacher and Siliverstovs, 2006) lack the long-term approach adopted in the present study. We believe that this long-run vision improves, for instance, our understanding of the effects of the growth of countries' market size. Previous research has been unable to reflect companies' possible entry into or exit from an industry, which is a key indicator of the presence of the "Home Market Effect" (HME) ${ }^{1}$. Following Baldwin and Krugman (1989), the entry-exit decisions of companies in a market or industry are influenced by the long-term growth of market size. Furthermore, in the few studies focused specifically on agricultural trade, these generally concentrate on brief periods or specific conjunctures rather than offer long-term visions. This is the case, for example, in Coyle et al. (1998), who concentrate on analyzing changes in the composition of agricultural trade between 1985 and 1995, and in Cho et al. (2002), a study of the effects of exchange rate volatility upon agricultural trade between 1974 and 1995.

The present article makes a second contribution by performing an analysis wider than that of previous research, including further variables we consider to be relevant. To this end, we have combined three research lines in the gravity equation methodology: the work of Bergstrand (1989), the studies by Feenstra et al. (1998 and 2003), and the latest contributions made by de Anderson and van Winncoop (2004). Furthermore, we attempt to further the debates regarding the influence of GATT and of different Regional Trade Agreements upon trade growth (Rose, 2004. Our research, due to its long-term perspective, offers a much more complete analysis of the possible influence of institutional frameworks upon trade, for the cases of both GATT and RTAs. While the majority of previous studies of agricultural trade flows analyzing this subject only take the specific case of one region or conjuncture into account, our long-term vision is able to produce results contradicting or validating studies such as those by Koo et al. (2006), for a cross-section in 1999, Jayasinghe and Sarker (2008), for NAFTA in the period 19852000, and Sarker and Jayasinghe (2007), for the period 1985-2000.

Finally, it must be emphasized that our study demonstrates that the correct estimation of the gravity equation must include fixed effects by country, to serve as an approximation of "multilateral resistance", following the suggestions made by Anderson and van Wincoop (2004). In addition, the standard errors must be corrected using a Prais-Winstein estimation, as otherwise the models are prone to problems of specification. We believe that from the econometric perspective we resolve some of the recurrent problems in estimation using panel data, in contrast to the great majority of studies focused on agricultural trade (Jayasinghe and Sarker, 2008; Sarker and Jayasinghe, 2007).

\footnotetext{
${ }^{1}$ See, for example, the analysis performed by Head and Ries (2001), which examines only six years. 
The following conclusions can be extracted from the present study. Firstly, the extremely limited importance of the home market effect for agricultural exchanges, which explains why these grew less dynamically than those of manufactures and total trade. Secondly, it is important to underline the negative sign of the income demand elasticity of imports in the agricultural and food products trade; this demonstrates behaved like inferior goods. Lastly, while other types of trade, such as manufactures, enjoyed greater multilateral liberalization of their markets, strong market intervention caused agricultural trade to base its growth on the proliferation and success of regional trade agreements.

The article is divided into three sections, followed by our conclusions. Following this introduction, Section 2 establishes the theoretical framework of gravity models, and explains the data employed and the procedure for estimating the gravity equation. Section 3 discusses the most important results, and the study ends with the presentation of our conclusions.

\section{Theoretical framework, data description and estimation procedure for the gravity equation}

The first applications of the gravity equation employed in the study of the determinants of international trade, undertaken by Tinbergen (1962) and Pöyhönen (1963), lacked a theoretical basis. Subsequently, the success of this methodological approach in explaining international trade patterns led economists to formally develop its theoretical foundations. The empirical validations of the gravity equation, such as those performed by Helpman (1987), Hummels and Levinsohn (1995), and Evenett and Kéller (2002), conclude that the equation can be derived from different theoretical models. This is an eclectic vision of trade determinants which includes, in a complementary fashion, the Hecksher-Ohlin models with specialization (Anderson, 1979; Deardorff, 1984; Anderson and van Wincoop, 2003) and the models of the New International Trade Theory with increasing returns and monopolistic competition (Helpman and Krugman, 1985), allowing the gravity equation to be better reconciled with the theoretical models.

The database and the specification of the equation employed in this article largely follow the studies by Feenstra et al. (1998), Bergstrand $(1985,1989)$ and Anderson and van Wincoop (2003) -in which a detailed explanation of their theoretical foundations can be found- and we therefore offer only a simple description of the variables, the sign and their expected results. Their functional form, applying logarithms, is: 


$$
\begin{aligned}
\ln X_{i j t} & =\beta_{1}+\beta_{2} \ln \left(Y_{i t}\right)+\beta_{3} \ln \left(Y_{j t}\right)+\beta_{4} \ln \left(Y_{p c p_{i t}}\right)+\beta_{5} \ln \left(Y_{p c p_{j t}}\right)+ \\
& +\beta_{6} \operatorname{lnDist}_{i j}+\beta_{7} \operatorname{lnExcvol}_{i j t}+\beta_{8} \operatorname{lnRem}_{i j t}+\beta_{9} \text { Border }_{i j}+ \\
& +\beta_{10} \operatorname{Lang}_{i j}+\beta_{11} \text { RTA }_{i j t}+\beta_{12} \text { GATT }_{i j t}+\delta_{i}+\delta_{j}+\varepsilon_{t}
\end{aligned}
$$

In our approach to the gravity equation, $\boldsymbol{X}_{i j t}$ represents the volume of trade flows between two countries, Dist $t_{i j}$; the geographic distance between the capitals of the countries of origin and destination (CEPPI database) and $\boldsymbol{Y}_{\boldsymbol{i t}} \boldsymbol{Y}_{\boldsymbol{j} t}$ the countries' market size, approximated by the value of their income (real GDP in year t, in 1985 US dollars, World Development Indicators, WDI database CD-ROM, 2004). This variable permits us to observe that the potential of a country to offer (export) its products depends on its own average market size, as measured by GDP, while foreign demand for these products will depend on the size of the GDP of the importing country.

Following Feenstra et al. (1998), the use of these variables also permits us to analyze to what degree different types of goods adapted to intra-industrial trade. This theoretical framework for the gravity equation provides a method for verifying the home market (or reverse home market) effect for different trade sectors. According to the above authors, in the case of differentiated products (manufactures) and increasing returns to scale, a country's exports respond more sensitively to changes in the income of the exporting country than to that of the importing country; this has been termed the home market effect. According to Krugman (1980), when countries trade, that which has a wider market will produce a large number of differentiated products, since it will attract more companies and will become a net exporter of differentiated products. In the case of homogenous products, their trade responds more sensitively to the income of the importing country than to domestic income. On this point, several studies, such as those by Feenstra et al. (1998) and Fidrmuc (2004), have provided evidence to show that agricultural trade should be framed within characteristic models of homogenous products and that its theoretical base is easier to reconcile with national product differentiation trade models or reciprocal dumping. These models are based on the idea that countries trade simply because certain products cannot be substituted (Armigton, 1969) and in this case the "reverse home market effect" occurs, as demonstrated by Head and Ries (2001) and Feenstra et al. (1998).

Moreover, as stated above, the geographical distance between countries is usually presented both as an obstacle to trade and as an approximation of transport costs. Various studies have debated this practise, pointing out that logistical infrastructure differs greatly among countries, and in consequence Rose (2000) proposes weighting the distance between countries $\left(\boldsymbol{R e m i}_{i j t}\right)$ on the basis of their income levels. 
However, following Bergstrand (1989), the equation includes the GDP per capita of the countries $\left(\boldsymbol{Y c p c}_{i t}, \boldsymbol{Y c p c}_{\boldsymbol{j t}}\right.$ ), in year t, in 1985 US dollars (WDI CD-ROM, 2004). Their inclusion in the model permits us to characterize trade in different types of goods. According to the abovementioned author, the coefficient of per capita income in the exporting country may be considered as an approximation of its factor endowment, its coefficient being positive in the case of capital-intensive goods and negative for labor-intensive goods. Likewise, the coefficient of per capita income in the importing country serves to categorize the type of good, and will produce a positive sign for superior goods and a negative one for inferior goods (Silverstovs and Schumacher, 2007).

As in the vast majority of studies, we simultaneously include multiple variables, such as geographical proximity (if the countries in question share a border) or cultural proximity; $\boldsymbol{B o r d e r}_{i j}$ is a dummy variable which takes the value of 1 if they have a common border and 0 otherwise; Lang $_{i j}$ is a dummy variable which takes the value of 1 if the countries share a common language and 0 otherwise. All of these are expected to produce positive signs for their coefficients. Moreover, following other studies, such as Cho et al. (2002) and Rose (2000), the model includes different measures of the volatility of the bilateral exchange rates in year $\mathrm{t}\left(\boldsymbol{E x c v o l}_{i j t}\right)^{2}$. The objective in the present case is to examine the impact of exchange rate uncertainty upon trade flows. Its coefficient is expected to display a negative sign i.e. the greater the instability of bilateral exchange rates, the lower will be the growth of trade between the two countries in question.

With regard to the institutional context, the specification of the gravity equation has been refined in many studies, in order to take into account those factors which may limit or stifle trade. Surprisingly, few such studies have introduced trade policies into the gravity equation, although their inclusion in the model is admittedly difficult, due to limited or non-existent data. Nevertheless, many studies have introduced dummy variables to analyze, on the one hand, the effect of regional liberalization produced by the proliferation of regional trade agreements (Frankel, 1997; Frankel and Wei, 1993) and, on the other, the effects of the multilateral liberalization of international markets.

$\boldsymbol{R} \boldsymbol{T} \boldsymbol{A}_{i j t}$ are dummy variables which take the value of 1 if the two countries belong to one of the following regional trade agreements (EU, NAFTA, CER, APEC, MERCOSUR, ANDEAN, ASEAN or GSTP, and 0 otherwise.

\footnotetext{
${ }^{2}$ Estimation of the standard deviation of the first difference of the annual natural logarithm of the nominal bilateral exchange rate, for both countries in the 10 years preceding the period $t$ (data for exchange rates taken from WDI CD-ROM, 2004)
} 
For the case of multilateral market liberalization, and following the proposal made by Rose (2004), two dummy variables were included to explore the effects of membership of a free trade association. $\boldsymbol{G A T T}_{i j t}$ are dummy variables aimed at capturing the impact of the various rounds of GATT. Concretely, GATT $_{63-94}$, is a dummy variable, used if the two countries belonged to that organism prior to the Uruguay Round (1994). Additionally, GATT $94-00$ is a dummy variable, employed if the two countries were members of GATT following the implementation of the agreements reached in the Uruguay Round (1994). The objective of this separation is to analyze, especially, the effects of the latter, which was the first round in which trade in agricultural and food products was liberalized. Both the result and the sign of this variable are uncertain, as stated in the introduction to the present study.

Lastly, in line with the recent work by Anderson and van Wincoop (2003), the equation includes the "multilateral (price) resistance terms" proxied by the dummy variables $\delta_{i}$ and $\delta_{j}$. This article, highly influential in recent studies, demonstrates that the omission of price indices leads to an erroneous specification of the empirical model, which may bias the results. We use country fixed effects $\left(\boldsymbol{\delta}_{\boldsymbol{i}}, \delta_{j}\right)$ to account for the multilateral price terms (rather than a custom nonlinear least squares program), following the alternative proposed by Feenstra (2004). These variables reflect the effect of all those particularities of the exporting or importing country which affect trade between them and are not captured by the remaining variables specified in the empirical model. Finally, the model includes the error term $\left(\varepsilon_{t}\right)$, which is assumed to be log-normally distributed.

Following the system of the Standard International Trade Classification (SITC, Revision 2 we constructed export flows by volume for total trade (all the SITC groups, 0-9.), manufactures (SITC groups: 5.Chemical products: 6.Manufactured products: 7.Machinery and equipment: 8.Various manufactures) and agricultural and food products (agricultural products included in the SITC groups 0004), in 1985 \$US and for the period 1963-2000 in year $\mathrm{t}\left(\boldsymbol{X}_{\boldsymbol{i j}}\right)$. These data were taken from the figures for bilateral exports (FOB - free on board) supplied by the United Nations Statistics Division in the UNCOMTRADE (2003) database. The sample includes trade among 40 countries $^{3}$. The database therefore consists of a "balanced data panel" comprising trade flows among 40 countries of origin x 39 countries of destination $\mathrm{x} 38$ years $=50,388$ observations $^{4}$.

\footnotetext{
3 Africa (Algeria, , Egypt, Morocco, Nigeria, Sudan, the Ivory Coast), Asia (China, India, Indonesia, Israel, Japan, Malaysia, Saudi Arabia); North America (Canada, México, United States); Latin America (Argentina, Brazil, Chile, Colombia, Ecuador, Nicaragua, Peru); Europe (Belgium-Luxembourg, Denmark, Finland, France, Germany, Greece, Italy, Ireland, Norway, Portugal, Spain, the Netherlands, the United Kingdom); Oceania (Australia, New Zealand)

4 In order to obtain a balanced panel trade flows with a value of 0 are replaced by a figure for minimum trade $(\$ 100)$, following previous research e.g. Raballand (2003) or Schumacher and Siliverstows (2006) having a similar specification to our approach to the gravity equation. The most common alternative to this method consists of eliminating those trade flows with a value of 0 . Frankel (1997) performs a comparative analysis of the two methods and 


\section{Insert Figure 1. Evolution.....}

Figure 1 shows the evolution of bilateral trade flows for international trade in agricultural and food products, manufactures and total trade, according to the data in the sample. As its examination reveals, the expansion of trade in agricultural and food products was slower than that of total trade and even more so compared to manufactures. Concretely, using the figures from the sample, while trade in manufactures increased almost eight-fold, by the end of the period agricultural trade had only multiplied 3.3 times.

With regard to the estimation technique, our aim was to overcome the limitations of previous research, which has only taken into account the variations among the units of observation (cross-section analysis). The present study also examines the time variations within the observation units. The use of panel data increases the efficiency of the estimators and significantly reduces the potential problems caused by the omission of variables (Hiaso, 1986). From this perspective, three types of data panel estimation are proposed: the first is the estimation of ordinary least squares (OLS) using the grouped panel; the second and third take into account the time variation, by including in the model random effects and fixed effects, respectively.

In order to determine which of the three estimators is most efficient, the LM Breusch-Pagan test for random effects was employed; it was concluded that random effects are significant and it was therefore preferable to use the estimation including them rather than the grouped panel estimation. Its results are given in columns 4-6 of Table 1. At first sight, the gravity equation presents satisfactory results, both for total trade and for agricultural and food products flows, and similarly for manufactures. The result of the adjusted $\mathrm{R}^{2}$ shows how the proposed model is able to explain $60 \%$ of the variations in world trade. Nevertheless, it should be emphasized that the equation has a lower explanatory capacity (52\%) in the case of trade in agricultural and food products. In general, the results clearly show, as initially forecast by the gravity equation, that the bigger the market size of countries and the shorter the distance between them, the greater is their reciprocal trade.

\section{Insert Table 1. Results....}

Similarly, to demonstrate that the inclusion of fixed effects is a more appropriate method than the two initially employed, various tests were performed. Firstly, the F-test (Greene, 2000) of the significance

finds negligible differences between the two alternatives. We have preferred the first approach, since it permits us to use more sophisticated econometric methods to correct the recurrent problems of estimation in previous research. Nevertheless, due to the drastic lack of data, exports from China, the Ivory Coast, Nigeria, Sudan, Saudi Arabia and Uruguay to the remaining countries were eliminated. Note that exports from the remaining countries to these countries remain in the sample. Thus, the sample comprises the trade flows among 40 countries of origin $x 39$ countries of destination $x 38$ years $-(6 \times 39 \times$ 38 trade flows were eliminated due to a lack of data) $=50,388$ observations. 
of fixed effects indicates that their estimations are more satisfactory than when the OLS estimation of the grouped panel is employed. Secondly, the Hausman test demonstrates that the estimators of random effects and of fixed effects differ significantly; furthermore, the fixed effects model provides a better explanation of the sources of variation and is therefore more appropriate than the random effects model.

It is important to underline at this point that, despite having modeled temporal and spatial heterogeneity according to a Wald test (Green, 2000), our model poses problems of heteroskedascity and, according to the Woolridge test (Wooldridge, 2001), problems of autocorrelation also exist. Lastly, the Breusch-Pagan test, used to identify problems of contemporaneous correlation in the residuals of the fixed effects model, likewise confirms the need to correct this problem. The above-mentioned problems of contemporaneous correlation, heteroskedascity and autocorrelation can be solved jointly and were resolved by the estimation of panel-corrected standard errors (PCSEs) ${ }^{5}$. On the positive side, once the problems of estimator specification were corrected, the models continued to function well. All the principal variables present the expected sign and are statistically significant (see columns 1-3 of table 1)

On this question, and in addition to these technical reasons, there are also theoretical justifications for preferring the fixed effects estimation (Feenstra 2004, 161-163). As stated earlier, Anderson and van Wincoop (2003) derived a gravity equation specification by using a model that includes the presence of “multilateral (price) resistant terms", which was approximated using fixed effects by country ${ }^{6}$. Furthermore, Baier and Bergstrand (2007) conclude that, for the analysis of trade agreements, the fixed effects approximation is best.

\section{Results}

The growth of GDP $\left(Y_{i t} Y_{j t}\right)$, for both total trade flows and those of manufactures and agricultural trade, displays higher coefficients than the remaining variables. However, the differential behavior of trade in agricultural and food products compared to other types of goods, such as manufactures, should be emphasized. While trade in the latter, as in total trade, was driven by the growth of market size in both the exporting and importing countries, agricultural trade flows were solely influenced by the growth in the market size of the importing country.

\footnotetext{
5 Beck and Katz (1995) demonstrate that the standard errors of PCSE are more precise than those of FGLS (estimation of Feasible Generalized Least Squares), the other alternative to solve the above-mentioned problems.

6 Following Feenstra (2004), the use of alternative methods produces similar results.

- 9 - 
Coinciding with previous research, this result implies, in the case of manufactures, the emergence of the home market effect (an effect which exceeds the growth in the market size of the exporting country compared to that of the importing country). That is to say, countries with large market sizes will attract companies which will specialize in the production of and trade in differentiated products and will take advantage of economies of scale.

Moreover, agricultural and food products adapted better to a trade pattern based on reciprocal dumping, as suggested by Feenstra et al. (1998 and 2003). Price dumping is price discrimination between markets which leads to trade in the same product between countries, in both directions. This trade pattern is entirely coherent with the generalized idea that intervention in the agricultural sector was extremely pronounced in the second half of the last century. Let us take as an example the case of agriculture in Western Europe. At least until the end of the 1980s European farmers received, for many products, as much as twice their international market price. The CAP, through its guaranteed prices policy, encouraged production, which would soon become surpluses to be placed on international markets at prices below domestic prices, via subsidies to exports.

The counterpart to the destination of these exports was the increasing demand for food in countries such as China, India and other emerging economies, due to their rising incomes. On this point, it must not be forgotten that such countries started from very low levels of per capita food consumption and, progressively, converged with the levels of high-income countries. Without a doubt, this helps us to understand the high coefficient (2.137) displayed by the income variable for the importing country $\left(Y_{j t}\right)$.

Secondly, the result in comparative terms displayed by the coefficient of per capita income of the importing country $\left(Y_{\left.p c p_{j t}\right)}\right.$ is notable, although unsurprising,: this was statistically significant and negative (-0.974) for the case of agricultural products, but positive (1.111) and also statistically significant for trade in manufactures. As stated earlier, this is one of the literature's most common explanations of the loss of share of products comprising agricultural trade in international markets. Thus, the low or negative income elasticity of the demand for imports of the majority of agricultural trade products hindered more dynamic behavior.

Furthermore, with regard to the effect upon trade of per capita income growth in the exporting country $\left(Y_{p c p_{i t}}\right)$, the results are more surprising. In the case of agricultural products the sign is positive (greater than unity) and statistically significant. In other words, a country's exports of agricultural and food products increased in line with its rising per capita income level. In the case of trade flows in 
manufactured products, the sign is the opposite i.e. as a country increased its income levels its exports of more elaborate products declined.

For our current concern, agricultural trade, the result is surprising but simpler to explain. Numerous studies have shown how, on the basis of technological innovation, significant improvements were made in productivity in agriculture, and how this became a capital-intensive sector for many economies (Federico, 2005). This factor, together with strong protectionism, consolidated numerous high-income countries as net exporters of agricultural and food products.

With regard to exchange rate volatility, this displayed negative and significant coefficients for total trade and for agricultural trade. Although their values are very low, it may be stated that when instability surrounded multilateral payments (as happened in the crises of the 1970s and 1990s), trade was negatively affected. Our results coincide with those of other studies, such as Cho et al. (2002), which demonstrate that agricultural trade was especially sensitive to such instability.

From an institutional perspective it is possible to talk of increasingly regionalized trade in agricultural and food products. The coefficients of the dummy variables EU, EFTA and GSTP are positive and statistically significant. The same is true for both total trade and trade in manufactures.

From a comparative perspective it is notable that the above-mentioned RTAs display their most expansive effects upon agricultural trade flows, which are also positively affected by $A P E C$ and $A S E A N$. All the foregoing leads us to affirm that trade in agricultural and food products was particularly regionalized, as RTAs generated an increase in trade flows greater than that of other sectors.

In our opinion, the greater influence of RTAs upon agricultural trade flows is also a reflection of the different degree of protectionism to which different trade sectors were subjected in the second half of the XX century. In other words, given the high degree of protectionism in agricultural markets, the effect of their liberalization among countries in the same region must, obviously, have been greater than in other sectors with lower barriers to trade, such as manufactures.

In the same vein, we attempted to test, for trade in various sectors, the importance of GATT membership. The results for total trade agree with those obtained by Rose (2004) i.e. the effects are not significant for total trade. However, a positive and significant sign was found for trade in manufactures. The dummy variables $G_{A T T_{62-94}}$ and $G_{A T T_{94-00}}$ display a positive and significant sign for the manufacturing sector. This effect was not evident for the agricultural sector, thereby confirming that agricultural trade was highly protected, at least until the Uruguay Round (1986-1994). 
Some authors have indicated a certain reduction of multilateral protectionism in agricultural markets, via the agreements established in the Uruguay Round (1986-94). Despite this, the coefficient of the

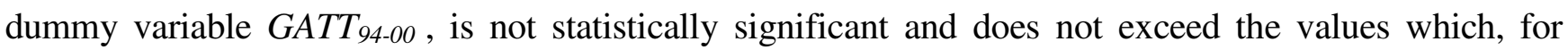
example, were found for the RTA coefficients.

\section{Conclusions}

The present study employs the gravity model to compare trade patterns for agricultural and food products, manufactures and total trade, using panel data for a large part of the second half of the XX century. Furthermore, the analysis constitutes an advance with respect to previous research, which has been based principally on cross-section studies. The vision presented here is longer-term and resolves some of the recurrent problems in estimation using panel data.

The results are robust with regard to various specifications and models. Five of the results achieved are of special interest and should be emphasized.

Firstly, trade in both agricultural and food products (and, by extension, trade in homogenous products) and manufactures is satisfactorily explained by the gravity equation.

Secondly, the evolution of income levels is the key factor to understanding the expansion of trade in not only agricultural and food products but also manufactures. This is no doubt closely related to the spectacular economic growth occurring during the second half of the XX century (Serrano and Pinilla, 2010). Nevertheless, it is especially notable that for trade in manufactures the home market effect was very important; this is typical of intra-industrial trade. The consequences of this result provide a startingpoint for understanding the loss of share of agricultural products in international markets i.e. their relatively low level of intra-industrial trade.

Thirdly, the negative sign of the income elasticity of demand for imports of agricultural trade and food products is notable; this proves that these may be categorized as inferior goods, and is consequently another very important factor for the understanding of their relative decline, since in the case of manufactures the sign is positive and the coefficient much higher. 
Fourthly, the proliferation of Regional Trade Agreements, especially in the European Union, exerted a much greater effect upon agricultural and food products than on other types of products. We believe that this reflects the different degrees of protectionism to which different trade sectors were subjected in the second half of the XX century. Studies such as those by Frankel and Rose (1998), Rose (2000) and Feenstra et al. (1998), Baier and Bergstrand (2007) and Endoh (2005) also corroborate our results i.e. that regional trade agreements are, in general, creators of trade. However, the present study finds no evidence of trade creation in the long term for APEC, NAFTA, CER, ANDEAN or ASEAN, and even shows trade diversion effects in the case of MERCOSUR. This is in contrast to the results of, for example, Frankel and Wei (1993, 1995) and Frankel (1997), regarding trade creation in the Asian and North American blocs for the period 1970-1992, and those of Soloaga and Winters (2001) for trade in Latin America in the 1990s.

Lastly, in our opinion there exist various reasons to believe that the relatively low growth of trade in agricultural and food products was also due to their facing stronger barriers to trade for a considerable part of the second half of the XX century. Especially notable are the above-mentioned increased growth of trade in zones with regional agreements, where obstacles to trade were lower, and the belated and insufficient effect of the GATT agreements upon the liberalization of agricultural trade. Finally, it must not be forgotten that the lower explanatory potential of models which analyze agricultural trade flows, which were strongly protected compared to others, such as trade in manufactures, apparently demonstrates the existence of other barriers to trade, which our model has been unable to capture.

Although not a central objective of this article, we believe that our results shed further light upon the controversial debate regarding the effects of Regional Trade Agreements. It can be stated that trade in agricultural and food products has become progressively regionalized, due especially to the establishment and widening of the $E U$ and the EFTA. More recently, in the last decade of the last century, we also find a positive effect for three preferential trade agreements, APEC, ASEAN and the GSTP. Our long-term vision produces results differing from those of Koo et al. (2006), for a cross-section in 1999, or those of Jayasinghe and Sarker (2008) for NAFTA in the period 1985-2000. However, our results agree with Fidrmuc (2004), for a cross-section in 1989, and Sarker and Jayasinghe (2007), for the period 1985-2000, with reference to the greater influence of, for example, the EU upon agricultural trade flows. 


\section{Acknowledgments}

This study has received financial support from the Ministry of Science and Innovation of the Spanish Government, project ECO2009-07796 and the Department of Science, Technology and Universities of the Government of Aragon, Research Excellence Group for 'Agri-food Economic History'. We are also grateful for the suggestions of the editor of the journal and the comments of the reviewers, and further wish to thank Ana Angulo, Albert Carreras, Domingo Gallego, Joan Ramon Rosés, Marcela Sabaté and Daniel Tirado for their comments.

\section{References}

Anderson, J.E. (1979) A theoretical foundation for the gravity equation, American Economic Review 69, 106-116.

Anderson, J.E. and Wincoop, E. van (2004) Gravity with Gravitas: a Solution to the Border Puzzle, American Economic Review 93 (1), 170-192.

Anderson, J.E. and Wincoop, E. van (2004) Trade Costs, Journal of Economic Literature 42, 691-751.

Aparicio, G., Pinilla, V. and Serrano, R. (2009) Europe and the international trade in agricultural and food products, 1870-2000, in Agriculture and Economic Development in Europe since 1870 (Eds) P. Lains and V. Pinilla. Routledge, London, pp 52-75.

Armington, P.S. (1969) A Theory of Demand for Products Distinguished by Place of Production, International Monetary Fund Staff Papers 16, 159-178.

Baier, S.L. and Bergstrand, J.H. (2007) Do free trade agreements actually increase member's international trade?, Journal of International Economics 71, 72-95

Baldwin, R. and Krugman, P. (1989) Persistent Effects of Large Exchange Rate Shocks, Quarterly Journal of Economics 104 (4), 635-654.

Beck, N. and Katz, J.N. (1995) What to Do (and Not to Do) with Time-Series Cross-Section Data, American Political Science Review 89, 634-647. 
Bergstrand, J.H. (1985) The gravity equation in international trade: some microeconomic foundations and empirical evidence, The Review of Economics and Statistics 67, 474-481.

Bergstrand, J.H. (1989) The generalized gravity equation, monopolistic, and the factor-proportions theory in international trade, The Review of Economics and Statistics 71, 143-153.

Cho, G., Sheldon, I. and McCorriston, S. (2002) Exchange rate uncertainty and agricultural trade, American Journal of Agricultural Economics 84, (4), 931-942.

Coyle, W., Gehlhar, M., Hertel, T., Wang, Z. and Yu, W. 1998) Understanding the Determinants of Structural Change in World Food Markets, American Journal of Agricultural Economics 80, (5), 1051-1061.

Deardorff, A. (1984) Testing trade theories and predicting trade flows, in Handbook of International Economics, (Eds.) R. Jones and P. Kenen, North Holland, Amsterdam, 467-517.

Dell'Aquila C, Sarker R and Meilke K (1999) Regionalism and Trade in Agrifood Products Union. Working paper 99-5, International Agricultural Trade Research Consortium.

Diao, X., Roe, T., and Somwaru, A. (2001) What is The Cause of Growth in Regional Trade: Trade Liberalization or RTA's?, World Economy 24,1, 51-79.

Endoh, M. (1999) Trade creation and trade diversion in the ECC, LAFTA and CMEA, 1961-1994, Applied Economics 31 (2), 207-216.

Evenett, S.J. and Keller, W. (2002) On theories explaining the success of the gravity equation, Journal of Political Economy 110 (2), 281-316.

FAO (1947-2000) Trade Yearbook FAO. Rome, Food and Agriculture Organization of the United Nations, Rome.

FAOSTAT (2004) FAOSTAT-Agriculture-Database. Rome, FAO. http://faostat.fao.org/default.aspx. (accessed September 2007).

Federico, G. (2005) Feeding the World. An Economic History of Agriculture, 1800-2000, Princeton University Press, Princeton.

Feenstra, R.C. (2004) Increasing returns and the gravity equation, in Advanced International Trade: Theory and Evidence, (Ed.) R Feenstra, Princeton University Press, Princeton. 
Feenstra, R.C., Markusen, J.A. and Rose A.K. (1998) Understanding the home market effect and the gravity equation: the role of differentiating goods, Working Paper, 6804, NBER, Cambridge.

Feenstra, R.C., Markusen, J.A. and Rose, A.K. (2003) Using the Gravity Equation to Differentiate among Alternatives. Theories of Trade, Canadian Journal of Economics 34 (4), 430-447.

Felbermayr, G. and Kohler, W. (2006) Exploting the Intensive and Extensive Margins of World Trade, Review of World Economics, 142 (4), 642-674.

Fidrmuck, J. (2004) The core and periphery of the world economy, The Journal of International Trade \& Economic Development 13 (1), 89-106.

Frankel, J. (1997) Regional trading blocs in the world economic system, Institute for International Economics, Washington, DC.

Frankel, J. and Rose, A. (1998) The Endogeneity of the Optimun Currency Area Criteria, Economic Journal 108,(449), 1009-1025

Frankel, J. and Wei, S. (1993) Continental trading blocs: Are they natural, or super-natural?, NBER Working Paper $N^{\circ}$ 4588, Cambridge, Mass.

Greene, W.H. (2000) Econometric Analysis, Prentice Hall International, London.

Head, K. and Ries, J. (2001) Increasing returns versus national product differentiation as an explanation for the pattern of US-Canada trade, American Economic Review 91, (4), 858-879.

Helpman, E. (1987) Imperfect Competition and International Trade: Evidence from Fourteen Industrial Countries, Journal of the Japanese and International Economies 1, (1), 62-81.

Helpman, E. and Krugman, P. (1985) Market Structure and Foreign Trade; Increasing Returns, Imperfect competition and the International Economy, MIT press, Cambridge, Mass.

Hiaso, C. (1986) Analysis of Panel Data, Econometric Society Monographs, Cambridge University Press: Cambridge.

Hummels, D. and Levinsohn, J. (1995) Monopolistic competition and international trade: Reconsidering the evidence, Quarterly Journal of Economics 110, 799-836. 
Jayasinghe, S. and Sarker, R. (2008) Effects of Regional Trade Agreements on Trade in Agrifood Products: Evidence from Gravity Modeling Using Disaggregated Data, Review of Agricultural Economics 30 (1), 61-81.

Jensen, P.E. (2006) Trade, entry barriers, and home market effects, Review of International Economics 14 (1), 104-118.

Koo, W., Kennedy, P.L. and Skripnitchenko, A. (2006) Regional Preferential Trade Agreements: Trade Creation and Diversion Effects, Review of Agricultural Economics 28 (3), 408-415.

Krugman, P. (1980) Scale Economies, Product Differentiation and the Pattern of Trade, American Economic Review 70, 950-59.

Krugman, P. (1995) Growing World Trade: Causes and Consequences, Brookings Papers on Economic Activity 1, 327-377.

Pöyhönen, A. (1963) A tentative model for the volume of trade between countries, Weltwirtschaftliches Archiv 90, 93-100.

Raballand, G. (2003) Determinants of the Negative Impact of Being Landlocked on Trade: An Empirical Investigation through the Central Asian Case, Comparative Economic Studies 45, 520-536.

Rose, A.K. (2000) One Money, One Market: Estimating the Effect of Common Currencies on Trade, Economic Policy 30, 7-45.

Rose, A.K. (2004) Do we Really Know That the WTO Increases Trade?, The American Economic Review 94 (1), 98-114.

Rose, A.K. (2005) Which International Institutions Promote International Trade? Review of International Economics 13 (4), 682-689.

Sarker, R. and Jayasinghe, S. (2007) Regional trade agreements and trade in agri-food products: evidence for the European Union from gravity modelling using disaggregated data, Agricultural Economics 37 (1), 93-104.

Schumacher, D. and Siliverstovs, B. (2006) Home-market and factor-endowment effects in a gravity approach, Review of World Economics, 127(2), 330-353.

Serrano, R. and Pinilla, V. (2010) Causes of world trade growth in agricultural and food products, 19512000: A demand function approach, Applied Economics, 42, 27, 3503-3518. 
Serrano, R. and Pinilla, V. (forthcoming): Terms of trade of agricultural and food products, 1951-2000, Revista de Historia Económica/Journal of Iberian and Latin American Economic History.

Silverstovs, B., Schumacher, D., (2007) Using the gravity equation to differentiate among alternative theories of trade: another look, Applied Economics Letters 14, 1065-1073.

Soloaga, I. and Winters, A. (2001) How has regionalism in the 1990s affected trade?, North American Journal of Economics and Finance 12, 1-29.

Subramanian, A. and Wei, S..J (2007) The WTO promotes trade, strongly but unevenly, Journal of International Economics 72, 151-175.

Timbergen, J. (1962) Shaping the World Economy, The Twentieth Century Fund, New York.

Tomz, M., Goldstein, J.L. and Rivers, D. (2007) Do We Really Know That the WTO Increases Trade? Comment, American Economic Review 97, 5, 2005-2018.

UN-COMTRADE (2003) UN Commodity Trade Statistics Database, Statistical Division of the United Nations, New York.- http://comtrade.un.org/db/ (accessed September 2007).

WDI cd-rom (2004) World development Indicators, World Bank, Washington DC.

Wooldridge J (2001) Econometric Analysis of Cross Section and Panel Data, MIT Press, Cambridge, MA. 


\section{TABLES AND FIGURES}

Figure 1. Evolution of Bilateral Flows of International Trade in Agricultural Products, Manufactures and Total Trade (Logarithmic scale, millions of 1985 \$US)

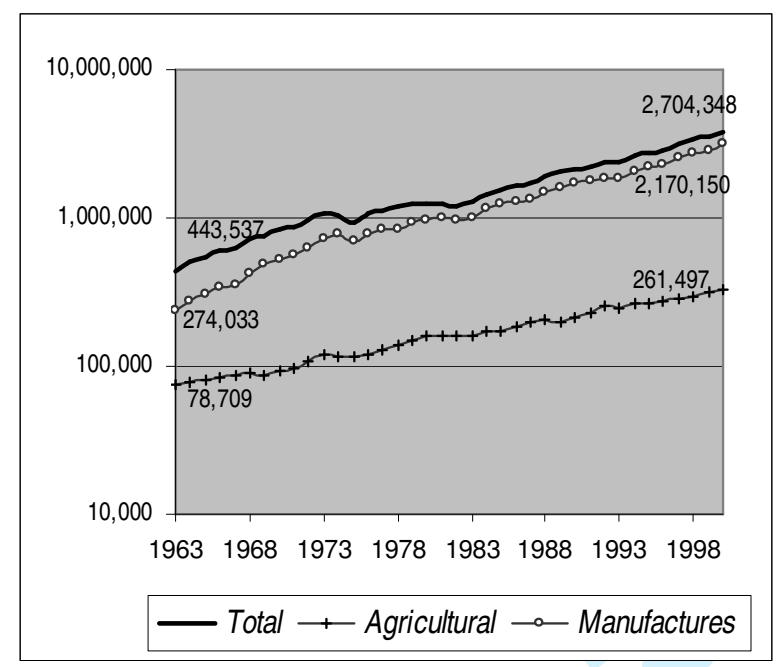


Table 1. Gravity Equation Results for International Trade in Agriculture, Manufactures and Total Trade

PCSE-FE

Fixed effects

Random effects

OLS grouped panel

\begin{tabular}{|c|c|c|c|c|c|c|c|c|c|c|c|c|}
\hline $\operatorname{Ln} X_{i j t}$ & $\begin{array}{c}\text { TOT } \\
\text { (1) }\end{array}$ & $\begin{array}{c}\text { MANF } \\
\text { (2) }\end{array}$ & $\begin{array}{l}\text { AGR } \\
\text { (3) }\end{array}$ & $\begin{array}{c}\text { TOT } \\
(4)\end{array}$ & $\begin{array}{l}\text { MANF } \\
\text { (5) }\end{array}$ & $\begin{array}{c}\text { AGR } \\
(6)\end{array}$ & $\begin{array}{c}\text { TOT } \\
\text { (7) }\end{array}$ & $\begin{array}{c}\text { MANF } \\
(8)\end{array}$ & $\begin{array}{c}\text { AGR } \\
(9)\end{array}$ & $\begin{array}{l}\text { TOT } \\
(10) \\
\end{array}$ & $\begin{array}{c}\text { MANF } \\
\text { (11) }\end{array}$ & $\begin{array}{c}\text { AGR } \\
(12)\end{array}$ \\
\hline$\overline{\ln Y_{i t}}$ & 0.692 ** & $2.277 * * *$ & $-0.572 *$ & $0.717 * * * *$ & $2.235 * * *$ & $-0.795 * * * *$ & $0.988 * * *$ & $1.624 * * * *$ & $0.548 * * * *$ & $1.184 * * * *$ & $1.597 * * * *$ & $1.036^{* * * *}$ \\
\hline $\ln Y_{j t}$ & $\begin{array}{c}(.390 * * * \\
(0.171)\end{array}$ & $\begin{array}{c}(0.2 / 9) \\
0.455^{* * * *} \\
(0.170)\end{array}$ & $\begin{array}{c}(0.353) \\
2.137 * * * \\
(0.220)\end{array}$ & $\begin{array}{c}(0.066) \\
1.241 * * * \\
(0.054)\end{array}$ & $\begin{array}{c}(0.069) \\
0.227 * * * \\
(0.056)\end{array}$ & $\begin{array}{c}(0.085) \\
1.972^{* * *} \\
(0.069)\end{array}$ & $\begin{array}{c}(0.032) \\
0.993 * * * \\
(0.027)\end{array}$ & $\begin{array}{c}(0.034) \\
0.779 * * * \\
(0.028)\end{array}$ & $\begin{array}{c}(0.042) \\
1.151 * * * \\
(0.035)\end{array}$ & $\begin{array}{c}(0.008) \\
1.039^{* * * *} \\
(0.007)\end{array}$ & $\begin{array}{c}(0.008) \\
0.955^{* * *} * \\
(0.008)\end{array}$ & $\begin{array}{c}(0.011) \\
1.083^{* * *} \\
(0.011)\end{array}$ \\
\hline $\operatorname{lnYpcp_{it}}$ & $\begin{array}{c}0.023 \\
(0.371)\end{array}$ & $\begin{array}{c}-1.160^{* * * *} \\
(0.339)\end{array}$ & $\begin{array}{c}1.566^{* * * *} \\
(0.419)\end{array}$ & $\begin{array}{c}0.286 * * * * \\
(0.079)\end{array}$ & $\begin{array}{c}-0.708^{* * * *}(0.083)\end{array}$ & $\begin{array}{c}1.987 * * * \\
(0.102)\end{array}$ & $\begin{array}{c}0.304 * * * \\
(0.039)\end{array}$ & $\begin{array}{c}0.226 * * * \\
(0.042)\end{array}$ & $\begin{array}{c}0.690 * * * \\
(0.052)\end{array}$ & $\begin{array}{c}0.395 * * * \\
(0.011)\end{array}$ & $\begin{array}{c}0.558 * * * \\
(0.124)\end{array}$ & $\begin{array}{c}0.323^{* * * *} \\
(0.016)\end{array}$ \\
\hline$\overline{l n Y p c p_{j t}}$ & $\begin{array}{l}-0.056 \\
(0.167)\end{array}$ & $\begin{array}{c}1.111^{* * * *} \\
(0.183)\end{array}$ & $\begin{array}{c}-0.974 * * * * \\
(0.223)\end{array}$ & $\begin{array}{l}-0.046 \\
(0.062)\end{array}$ & $\begin{array}{c}1.181 * * * \\
(0.064)\end{array}$ & $\begin{array}{c}-0.869^{* * * *} \\
(0.079)\end{array}$ & $\begin{array}{c}0.110^{* * * * *} \\
(0.029)\end{array}$ & $\begin{array}{c}0.357 * * * * \\
(0.032)\end{array}$ & $\begin{array}{l}-0.010 \\
(0.039)\end{array}$ & $\begin{array}{c}0.109^{* * * *} \\
(0.008)\end{array}$ & $\begin{array}{c}0.022 * * \\
(0.009)\end{array}$ & $\begin{array}{c}0.195^{* * * *} \\
(0.017)\end{array}$ \\
\hline$\overline{\ln E^{2 x c v o l}} l_{i j t}$ & $\begin{array}{c}-0.055^{* * * *} \\
(0.012)\end{array}$ & $\begin{array}{c}-0.012 \\
(0.012)\end{array}$ & $\begin{array}{l}-0.030^{*} \\
(0.016)\end{array}$ & $\begin{array}{c}-0.091 * * * * \\
(0.006)\end{array}$ & $\begin{array}{c}-0.042^{* * * *} \\
(0.006)\end{array}$ & $\begin{array}{c}-0.049 * * * \\
(0.008)\end{array}$ & $\begin{array}{c}-0.099 * * * * \\
(0.006)\end{array}$ & $\begin{array}{c}-0.005^{* * * *} \\
(0.006)\end{array}$ & $\begin{array}{c}-0.063^{* * *} \\
(0.008)\end{array}$ & $\begin{array}{c}-0.129^{* * * *} \\
(0.008)\end{array}$ & $\begin{array}{c}-0.114^{* * * *} \\
(0.008)\end{array}$ & $\begin{array}{c}-0.087 * * * * \\
(0.010)\end{array}$ \\
\hline$\overline{l n \text { Dist }_{i j}}$ & & $\ldots$ & & $\ldots$ & $\ldots$ & $\ldots$ & $\begin{array}{c}-0.984 * * * * \\
(0.060)\end{array}$ & $\begin{array}{c}-1.217^{* * * *} \\
(0.065)\end{array}$ & $\begin{array}{c}-0.956^{* * * *} \\
(0.079)\end{array}$ & $\begin{array}{c}-1.022 * * * * \\
(0.014)\end{array}$ & $\begin{array}{c}-1.231^{* * * *} \\
(0.015)\end{array}$ & $\begin{array}{c}-1.012 * * * * \\
(0.019)\end{array}$ \\
\hline $\operatorname{lnRem}_{i t}$ & $\begin{array}{l}-0.000 \\
(0.005) \\
\end{array}$ & $\begin{array}{c}0.000 \\
(0.006) \\
\end{array}$ & $\begin{array}{l}-0.001 \\
(0.006) \\
\end{array}$ & $\begin{array}{l}0.019^{*} \\
(0.010) \\
\end{array}$ & $\begin{array}{c}0.017 \\
(0.010) \\
\end{array}$ & $\begin{array}{c}0.011 \\
(0.013) \\
\end{array}$ & $\begin{array}{c}0.037 * * * \\
(0.010) \\
\end{array}$ & $\begin{array}{c}0.008 \\
(0.010) \\
\end{array}$ & $\begin{array}{c}0.059 * * * \\
(0.013)\end{array}$ & $\begin{array}{c}0.103^{* * *} * \\
(0.012)\end{array}$ & $\begin{array}{c}-0.136^{* * * *} \\
(0.014)\end{array}$ & $\begin{array}{c}0.317 * * * * \\
(0.030)\end{array}$ \\
\hline$\overline{\text { Border }_{i j}}$ & $\ldots$ & $\ldots$ & $\ldots$ & $\cdots$ & $\ldots$ & $\ldots$ & $\begin{array}{l}-0.228 \\
(0.281)\end{array}$ & $\begin{array}{l}-0.316 \\
(0.303)\end{array}$ & $\begin{array}{c}0.297 \\
(0.371)\end{array}$ & $\begin{array}{c}-0.411^{* * * *}(0.164) \\
\end{array}$ & $\begin{array}{c}-0.399 * * * * \\
(0.067)\end{array}$ & $\begin{array}{c}-0.231 \text { **** } \\
(0.072)\end{array}$ \\
\hline Lang $_{i j}$ & & $\cdots$ & & $\ldots$ & & $\ldots$ & $\begin{array}{c}0.965^{* * * *} \\
(0.165)\end{array}$ & $\begin{array}{c}1.378 * * * \\
(0.178)\end{array}$ & $\begin{array}{c}1.411 * * * \\
(0.218)\end{array}$ & $\begin{array}{c}1.043^{* * * *} \\
(0.033)\end{array}$ & $\begin{array}{c}1.439 * * * \\
(0.036)\end{array}$ & $\begin{array}{c}1.458^{* * * *} \\
(0.043)\end{array}$ \\
\hline$\overline{E U}$ & $\begin{array}{c}0.234 * * * \\
(0.041) \\
\end{array}$ & $\begin{array}{c}0.183 * * * \\
(0.042) \\
\end{array}$ & $\begin{array}{c}0.319 * * * \\
(0.062)\end{array}$ & $\begin{array}{c}0.359 * * * \\
(0.053) \\
\end{array}$ & $\begin{array}{c}0.221^{* * * *} \\
(0.055) \\
\end{array}$ & $\begin{array}{c}0.396^{* * * *} \\
(0.068)\end{array}$ & $\begin{array}{c}0.288^{* * * *} \\
(0.052) \\
\end{array}$ & $\begin{array}{c}0.193 * * * \\
(0.054) \\
\end{array}$ & $\begin{array}{c}0.394 * * * \\
(0.066)\end{array}$ & $\begin{array}{c}-0.677 * * * * \\
(0.133)\end{array}$ & $\begin{array}{c}-0.827 * * * * \\
(0.036)\end{array}$ & $\begin{array}{c}0.140^{* * * *}(0.043) \\
\end{array}$ \\
\hline EFTA & $\begin{array}{c}0.177^{* * * *} \\
(0.055)\end{array}$ & $\begin{array}{c}0.276^{* * * *} \\
(0.078)\end{array}$ & $\begin{array}{c}0.459^{* * * *} \\
(0.097)\end{array}$ & $\begin{array}{c}0.337 * * * \\
(0.120)\end{array}$ & $\begin{array}{c}0.571 * * * \\
(0.125)\end{array}$ & $\begin{array}{c}0.782 * * * * \\
(0.153)\end{array}$ & $\begin{array}{c}0.358^{* * * *} \\
(0.119)\end{array}$ & $\begin{array}{c}.570 * * * * \\
(0.124)\end{array}$ & $\begin{array}{c}0.742^{* * * *} \\
(0.153)\end{array}$ & $\begin{array}{c}0.052 \\
(0.829)\end{array}$ & $\begin{array}{c}0.451^{* * * *} \\
(0.064)\end{array}$ & $\begin{array}{c}-0.282^{* * * *} \\
(0.096)\end{array}$ \\
\hline$\overline{A P E C}$ & $\begin{array}{c}0.083 \\
(0.121)\end{array}$ & $\begin{array}{c}0.209 \\
(0.150)\end{array}$ & $\begin{array}{c}0.313^{* *} \\
(0.153)\end{array}$ & $\begin{array}{c}0.108 \\
(0.071)\end{array}$ & $\begin{array}{c}0.342 * * * \\
(0.074)\end{array}$ & $\begin{array}{c}0.465^{* * * *} \\
(0.091)\end{array}$ & $\begin{array}{c}0.110 \\
(0.071)\end{array}$ & $\begin{array}{c}0.403 * * * * \\
(0.074)\end{array}$ & $\begin{array}{c}0.420 * * * * \\
(0.091)\end{array}$ & $\begin{array}{c}0.829 * * * \\
(0.058)\end{array}$ & $\begin{array}{c}0.966 * * * \\
(0.078)\end{array}$ & $\begin{array}{c}1.243^{* * * *} \\
(0.090)\end{array}$ \\
\hline NAFTA & $\begin{array}{c}0.108 \\
(0.112)\end{array}$ & $\begin{array}{l}-0.051 \\
(0.124)\end{array}$ & $\begin{array}{l}-0.099 \\
(0.132)\end{array}$ & $\begin{array}{c}0.293 \\
(0.258)\end{array}$ & $\begin{array}{l}-0.119 \\
(0.269)\end{array}$ & $\begin{array}{l}-0.162 \\
(0.331)\end{array}$ & $\begin{array}{c}0.279 \\
(0.258)\end{array}$ & $\begin{array}{l}-0.180 \\
(0.271)\end{array}$ & $\begin{array}{l}-0.187 \\
(0.332)\end{array}$ & $\begin{array}{c}-0.911 * * * * \\
(0.203)\end{array}$ & $\begin{array}{c}-1.418^{* * * *} \\
(0.296)\end{array}$ & $\begin{array}{c}-1.464 * * * * \\
(0.241)\end{array}$ \\
\hline$\overline{C E R}$ & $\begin{array}{l}-0.093 \\
(0.090)\end{array}$ & $\begin{array}{l}-0.121 \\
(0.118)\end{array}$ & $\begin{array}{l}-0.152 \\
(0.122)\end{array}$ & $\begin{array}{c}0.115 \\
(0.811)\end{array}$ & $\begin{array}{l}-0.088 \\
(0.745)\end{array}$ & $\begin{array}{l}-0.067 \\
(1.038)\end{array}$ & $\begin{array}{c}0.533 \\
(0.698)\end{array}$ & $\begin{array}{c}0.419 \\
(0.736)\end{array}$ & $\begin{array}{c}0.302 \\
(0.904)\end{array}$ & $\begin{array}{c}1.009 * * * \\
(0.066)\end{array}$ & $\begin{array}{c}1.314 * * * \\
(0.087)\end{array}$ & $\begin{array}{c}0.857^{* * * *} * \\
(0.185)\end{array}$ \\
\hline MERCOSUR & $\begin{array}{c}-0.303 * * \\
(0.136)\end{array}$ & $\begin{array}{c}-0.346^{* * *} \\
(0.139)\end{array}$ & $\begin{array}{l}-0.221 \\
(0.233)\end{array}$ & $\begin{array}{c}-0.787 * * * * \\
(0.220)\end{array}$ & $\begin{array}{c}-0.825 * * * * \\
(0.230)\end{array}$ & $\begin{array}{c}-0.726^{* * *} \\
(0.281)\end{array}$ & $\begin{array}{c}-0.724 * * * * \\
(0.220)\end{array}$ & $\begin{array}{c}-0.714 * * * * \\
(0.230)\end{array}$ & $\begin{array}{c}-0.641^{* * *} \\
(0.283)\end{array}$ & $\begin{array}{c}1.438^{* * * * *} \\
(0.127)\end{array}$ & $\begin{array}{c}1.409 * * * \\
(0.157)\end{array}$ & $\begin{array}{c}2.686^{* * * * *} \\
(0.164)\end{array}$ \\
\hline$\overline{A N D E A N}$ & $\begin{array}{c}0.208 \\
(0.127) \\
\end{array}$ & $\begin{array}{c}0.293^{* * *} \\
(0.132) \\
\end{array}$ & $\begin{array}{c}0.027 \\
(0.204) \\
\end{array}$ & $\begin{array}{l}0.336^{*} \\
(0.180) \\
\end{array}$ & $\begin{array}{c}0.462 * * \\
(0.187) \\
\end{array}$ & $\begin{array}{c}0.046 \\
(0.230) \\
\end{array}$ & $\begin{array}{c}0.390 * * \\
(0.177) \\
\end{array}$ & $\begin{array}{c}0.547 * * * \\
(0.185) \\
\end{array}$ & $\begin{array}{c}0.072 \\
(0.228) \\
\end{array}$ & $\begin{array}{c}2.563^{* * *} * \\
(0.095)\end{array}$ & $\begin{array}{c}3.023^{* * *} * \\
(0.098)\end{array}$ & $\begin{array}{c}2.910^{* * *} \\
(0.120)\end{array}$ \\
\hline$\overline{A S E A N}$ & $\begin{array}{l}0.769^{*} \\
(0.448)\end{array}$ & $\begin{array}{c}0.177 \\
(0.444)\end{array}$ & $\begin{array}{l}1.166^{* * *} \\
(0.474)\end{array}$ & $\begin{array}{c}0.753 \\
(0.590)\end{array}$ & $\begin{array}{l}-0.320 \\
(0.616)\end{array}$ & $\begin{array}{c}1.148 \\
(0.756)\end{array}$ & $\begin{array}{c}0.893 \\
(0.548)\end{array}$ & $\begin{array}{c}0.115 \\
(0.576)\end{array}$ & $\begin{array}{l}1.296^{*} \\
(0.707)\end{array}$ & $\begin{array}{c}2.415^{* * * *} \\
(0.134)\end{array}$ & $\begin{array}{c}.450 * * * \\
(0.137)\end{array}$ & $\begin{array}{c}2.965^{* * * *} \\
(0.124)\end{array}$ \\
\hline$\overline{G S T P}$ & $\begin{array}{c}0.761^{* * * *} \\
(0.154)\end{array}$ & $\begin{array}{c}0.585^{* * * *} \\
(0.136)\end{array}$ & $\begin{array}{c}0.805^{* * * *} \\
(0.169)\end{array}$ & $\begin{array}{c}1.143^{* * * *} \\
(0.043)\end{array}$ & $\begin{array}{c}0.933^{* * * *} \\
(0.045)\end{array}$ & $\begin{array}{c}1.289^{* * * *} \\
(0.055)\end{array}$ & $\begin{array}{c}1.068^{* * * *} \\
(0.040)\end{array}$ & $\begin{array}{c}0.903^{* * * *} \\
(0.042)\end{array}$ & $\begin{array}{c}1.075^{* * * *} \\
(0.052)\end{array}$ & $\begin{array}{c}-0.054 \\
(0.066)\end{array}$ & $\begin{array}{c}-0.096^{*} \\
(0.174)\end{array}$ & $\begin{array}{c}-0.622 * * * * \\
(0.088)\end{array}$ \\
\hline Gatt $_{62-94}$ & $\begin{array}{c}0.045 \\
(0.069)\end{array}$ & $\begin{array}{c}0.184 * * \\
(0.077)\end{array}$ & $\begin{array}{c}0.059 \\
(0.093)\end{array}$ & $\begin{array}{c}-0.094 * * * * \\
(0.033)\end{array}$ & $\begin{array}{c}0.127 * * * \\
(0.035)\end{array}$ & $\begin{array}{l}-0.011 \\
(0.043)\end{array}$ & $\begin{array}{c}-0.069 * * \\
(0.032)\end{array}$ & $\begin{array}{c}0.206 * * * \\
(0.034)\end{array}$ & $\begin{array}{l}-0.020 \\
(0.042)\end{array}$ & $\begin{array}{c}0.460 * * * \\
(0.032)\end{array}$ & $\begin{array}{c}1.204 * * * * \\
(0.034)\end{array}$ & $\begin{array}{c}0.694 * * * * \\
(0.043)\end{array}$ \\
\hline Gatt $94-00$ & $\begin{array}{c}0.092 \\
(0.089)\end{array}$ & $\begin{array}{c}0.223^{* *} \\
(0.098)\end{array}$ & $\begin{array}{c}0.177 \\
(0.109)\end{array}$ & $\begin{array}{c}-0.028 \\
(0.039)\end{array}$ & $\begin{array}{c}0.184 * * * * \\
(0.041)\end{array}$ & $\begin{array}{c}0.206^{* * *} * \\
(0.050)\end{array}$ & $\begin{array}{c}-0.057 \\
(0.038)\end{array}$ & $\begin{array}{c}0.233^{* * * *} \\
(0.040)\end{array}$ & $\begin{array}{c}0.129 * * \\
(0.049)\end{array}$ & $\begin{array}{c}0.450^{* * * *} \\
(0.037)\end{array}$ & $\begin{array}{c}1.215^{* * * *} \\
(0.004)\end{array}$ & $\begin{array}{c}0.887^{* * * *} \\
(0.054)\end{array}$ \\
\hline Constant & $\begin{array}{c}-37.81 * * * * \\
(4.452)\end{array}$ & $\begin{array}{c}-56.24^{* * *} \\
(4.139) \\
\end{array}$ & $\begin{array}{c}-30.62 * * * \\
(4.663)\end{array}$ & $\begin{array}{c}-34.65 * * * \\
(1.069) \\
\end{array}$ & $\begin{array}{c}-50.84 * * * \\
(1.114) \\
\end{array}$ & $\begin{array}{c}-25.26^{* * * *} \\
(1.369)\end{array}$ & $\begin{array}{c}-28.21 * * * \\
(0.817) \\
\end{array}$ & $\begin{array}{c}-40.11^{* * *} * \\
(0.872)\end{array}$ & $\begin{array}{c}-26.15^{* * *} \\
(1.070)\end{array}$ & $\begin{array}{c}-34.49^{* * *} \\
(0.344) \\
\end{array}$ & $\begin{array}{c}-45.16^{* * *} \\
(0.354)\end{array}$ & $\begin{array}{c}-32.66^{* * * *} \\
(0.498) \\
\end{array}$ \\
\hline No of observations & 50.388 & 50.388 & 50.388 & 50.388 & 50.388 & 50.388 & 50.388 & 50.388 & 50.388 & 50.388 & 50.388 & 50.388 \\
\hline Adjusted $R^{2}$ & 0.600 & 0.625 & 0.517 & 0.260 & 0.352 & 0.187 & 0.644 & 0.687 & 0.492 & 0.659 & 0.716 & 0.530 \\
\hline
\end{tabular}

Note: TOT: total trade, MANF: trade in manufactures, AGR: trade in agricultural and food products.

Columns 10-12: Estimation of grouped panel with ordinary least squares. Columns 7-9 with random effects model, 4-6 with fixed effects model. Columns 1-3: Prais-Winstein estimation with PCSE and fixed effects. All variables are in logarithms, except for binary variables (common border, language, RTAs and GATT). Standard errors are given in parentheses. $* * *, * *$ and $*$ denote statistical significance at the $1 \%$,

$5 \%$ and $10 \%$ level, respectively.

Editorial Office, Dept of Economics, Warwick University, Coventry CV4 7AL, UK 

西 10 